\title{
Pandemic Preparedness and Techno Stress among Faculty of DAIs in Covid-19
}

\author{
* Mahwish Zeeshan, Lecturer (Corresponding Author) \\ ** Dr. Abid Ghafoor Chaudhry, Associate Professor \\ *** Shaheer Ellahi Khan, Assistant Professor
}

\begin{abstract}
Amid COVID-19 pandemic in Pakistan, the Higher Education Commission of Pakistan announced the closure of all public and private universities and Higher Education Institutes from mid of March 2020. The paper highlights the issues faced by the university faculty in terms of techno-stress due to a lack of pandemic preparedness. The data gathered for this research is qualitative using the exploratory methodology. The methods of the study are In-depth interviews and FGDs. Interview guide and FGD Checklist are tools employed to gather data from the faculty of sixteen Pakistani universities which is sorted thematically and illustrated through descriptive statistics. The findings of the study suggest that the global pandemic has seriously affected the higher education sector in Pakistan. The private universities and the heavily funded public universities have taken off in a bullish mode. However, the public sector universities are coping up in a bearish trend. The faculty's response also corresponds with the transition to online teaching. Besides the university's efforts to ease out learning through an online interface, the majority of the faculty is feeling overburdened with additional responsibilities about online teaching. The study highlights the gap between policymaking and the on-ground situation of the universities in terms of online readiness.
\end{abstract}

Keywords: Covid-19, Online Readiness, On-line Teaching, Pandemic, Techno-stress, Tech-savvy, Introduction University Faculty

COVID-19 has been declared as a global pandemic by WHO a couple of months ago (WHO, 2020). This recent pandemic is majorly a health crisis; however, it has affected almost all domains of life. One of the most vulnerable sectors is education which has been forced to abruptly switching to the online mode of instruction at an unprecedented scale (Pasha, 2020). It is also believed that the intense effects of the SARs-severe acute respiratory syndrome may change the future of education forever (Rose, 2020). Universities in Pakistan are seriously facing this dilemma since they bring hundreds of students, researchers, and faculty together daily for the dissemination of knowledge and hence are exceptionally vulnerable to this disease (HEC, 2020). Many educational institutions have simply called off their exams and assessment, some have given a break to the students, some announced an early summer break, some have ceased their semesters whereas most of them are in the process of transition by shifting the entire academic system to on-line mode.

On one hand, the pandemic requires isolation and social distancing on the other people need to get back united to reinstall the halted system. Governments across the globe are stepping up their efforts in providing training and support for adaptation to this new mode of teaching. Academicians around the world are managing communication with students through virtual classrooms, social media platforms such as What's App, Google classroom, Zoom, Face book, and several online learning management systems. They are hovering around 1.5 billion students affected due to the closure of educational institutions through distance teaching (UNESCO, 2020). The South Asian universities such as those from Afghanistan, Pakistan, and India are finding themselves ill-prepared to switch to remote or online learning (Khan, Niazi, \& Saif, 2020).

This Trans in education is raising inequality among students on one hand and stresses amongst faculty on the other. The development of this pandemic has led to serious implications for

\footnotetext{
* Department of Anthropology, PMAS-Arid Agriculture University, Rawalpindi

Email: mahwish.zeeshan@uaar.edu.pk

** Department of Anthropology, PMAS-Arid Agriculture University, Rawalpindi Email: abidgc@ uaar.edu.pk

*** Department of Humanities and Social Sciences, Bahria University Islamabad

Email: Sellahi.buic@bahria.edu.pk
} 
the higher education public institutions and raises particular questions (Ahmed, Allaf, \& Elghazaly, 2020). The current research has taken into account one such question about the challenges faced by academia in coping with the amounting 'techno-stress' emerging out of online teaching and calling them out for 'online readiness'. To counter COVID-19, several governments are using advanced surveillance technologies that are causing techno-stress among citizens (Bartoszko, 2020). Researches concerning the time spent on online teaching suggest that it is double or triple of the online on-ground teaching (Palloff \& Pratt, 2007). The techno stresses faced by the academic community in online teaching are similar with a few exceptions about their field. The case adds to a new dimension of the phenomenon of techno-insecurity which means that they are feeling in the situation where online teaching is compulsory and those who do not have an understanding of educational technology and gadgets may lose it to the ones who are better acquainted with it (Tarafdar, Qiang, Ragu-Nathan, \& Ragu-Nathan, 2007).

The academia from the public sector universities is yet the 'fortunate ones' who have their jobs secured as yet and have sought the opportunity to work from home (Pickup, 2020). However, emergent mode of online education in universities is believed to address the unprecedented challenges faced in the continuation of education. The undercurrent of anxiety in this new mode of interaction is equally stressing the faculty especially those who are striving their level best to keep up the pace with the online mode of teaching in a developing country like Pakistan where there are several infrastructure voids such as; power breakups, slow and disruptive connectivity, lack of access to fast internet and reaching out to students across the country.

\section{Objectives}

1. To find out the strategies and tools used by general and specialized universities and the response from their faculty in its adoption.

2. To study the policy recommendations of the higher education commission on the continuation of education in COVID-19 pandemic

3. To explore the issues faced by the faculty in coping up with online education.

4. To bring forth the current situation and challenges of universities.

\section{Research Questions}

1. What experiments have been done by universities for online teaching?

2. What is the current situation of the university and faculty for 'online readiness?

3. How is the faculty managing this shift?

4. What is the on-ground situation of universities for the adoption of online teaching?

\section{Literature Review}

Technology is transforming the modes of teaching and learning alongside. The use of technology for online teaching has not been fully embraced to date. The pace is slow and often caught with ambivalence and conflict within the classroom (Mitchell, Parlamis, \& Claiborne, 2015). International educational institutions like Harvard and MIT had initiated such programs back in 2012 but in the developing world; it is pretty early to switch to online teaching while keeping all the stakeholders on board. Online learning can be a highly politicized term that can take several interpretations one wants to advance with. However, we are only concerned with online education which is the only resort to continue educating university students without disruption in a pandemic like COVID-19. Though, it has demanded enormous transformation in teaching and adaptation with educational technology at an unprecedented rate. There is a need to understand the difference between 'online education' and an 'emergency response' to continue educating students remotely posed by a pandemic. Online wellplanned teaching is meaningful and a matter of choice and hence stands different from teaching remotely in emergencies (Hodges, Moore, Lockee, Trust, \& Bond, 2020). Faculty, students, parents, University administration, and the Higher Education Commission should understand the difference between the two while assessing the teachers and their online readiness for teaching.

The drastic step of closure of all the universities in Pakistan is taken in the mid of March amid the global pandemic outbreak. Closure of education institutions is a highly-priced step that is and has to be paid by the entire society due to disruption of the academic cycle and abrupt changes in the academic calendar. Currently, two imperatives are leading the policies of the Higher Education Commission of Pakistan (HEC, 2020). Firstly to support the government in the containment of the pandemic by the closure of educational institutions and secondly minimizing the academic disruption 
by moving to the online medium of instruction at the earliest since the current lockdown was initially supposed to last till May $31^{\text {st }}$ (Khattak, 2020), but it is likely to be extended beyond July $15^{\text {th }}$ as per the chairman of the HEC (Pakistan Today, 2020). Since no one knows for how long the crisis will last. The decision for switching classes to online mode has received a lot of criticism from the masses. The critics belong to two major camps; the one who believes that university students should also be promoted to next semesters without examination and the other which is striving hard to continue educating their students irrespective of the challenges to contribute to the national cause.

Pakistani universities have been facing massive migration from traditional face to face teaching to online teaching as of sudden closure of educational institutes since March $13^{\text {th }}, 2020$ (Latif $\&$ Sajid, 2020). The Higher Education Commission of Pakistan has introduced a concept of 'online readiness' (Wladis \& Samuels, 2016) for ensuring the quality of online education in Pakistani universities. HEC has requested the Vice-Chancellors of all the universities to personally certify six key elements indicating the 'online readiness of the Universities' which comprises; University readiness, faculty readiness, course readiness, library readiness, course readiness, and lastly student readiness (HEC, 2020). Mostly public sector universities are currently striving to achieve the $1^{\text {st }}$ objective; university readiness which is the first imperative of online teaching by providing a technological infrastructure able enough to support online teaching systems with the help of the administration and technical assistance. HEC has directed all the universities to conduct surveys from their respective students on checking out the sixth indicator; student readiness. This paper deals with the $2^{\text {nd }}$ type of 'online readiness, which is the faculty readiness for online teaching which has been ignored and unaddressed by most of the public sector universities.

There is a cultural assumption among the university faculty that online teaching cannot assure learning and the quality is not assured (Allen, Seaman, Lederman, \& Jaschik, 2012) \& (Lin, Singer, $\&$ Ha, 2010). There has been an assumption that universities with online teaching programs are merely factories making money and producing degree holders incapable of the skills required for conferment of their respective degrees (Mitchell, Parlamis, \& Claiborne, 2015). However, this pandemic has not left it optional for universities and teachers to offer online programs, it is rather the need of the hour which has transformed the cultural paradigm of traditional learning. Since we have been accustomed to instructor-centered teaching in the Higher Education sector, it is assumed that face to face learning ensures learning by non-verbal cues as well which gets difficult in online teaching (Parlamis \& Mitchell, 2014).

A recent study in the higher education sector; Peking university in China suggests that most of the faculty are feeling challenged to cope up with the sudden shift to online teaching since it requires an expansive work on lesson plans, early preparation, online curriculum development and support from the technical support teams. Continuing online solely especially in professional education programs such as Medical, Engineering, and Information Technology is however not possible (Bao, 2020). Tech-savvy faculty have adapted to online solutions comparatively more swiftly than those who still are not well versed with the modern teaching technologies and are fearful of technology. Psychosocial distress is a result of the perceived workload among university faculty especially in bureaucratic practices that leads to negative perceptions of workload among university faculty (Pace, D'Urso, Zappulla, \& Pace, 2019). In a recent study carried out to study primary stress factors among online university teachers, the expert panel coincides with the cognitive dimension of work; both qualitatively and quantitatively based on the complexity of information and sustained attention span (García-González, Torrano, \& García-González, 2020). The findings suggest that most of the faculty is not mentally contented with the online teaching model which as a result is affecting their mental health.

In current teaching scenario posed by COVID-19 pandemic where all the universities have called off face to face interaction and teaching, reliance on technology has amplified, effective management of ICT is the main tool of teaching to reduce techno stressors (García-González, Torrano, \& García-González, 2020). Since employees have started to work more in isolation due to working online or work from home, a further burden emerges from resilience on technology that has been termed as 'techno strain' (Salanova, Llorens, \& Cifre, 2013). Techno strain of techno-stress unveils the hidden vulnerabilities of employees in terms of efficacy related to the use of technology (Pickup, 2020). In a study carried out among university faculty on 531 teachers, it was found that the 
pace of work in meeting the deadlines is attributed as a stressor among workers when the volume of work demands off working hours (Malik, Björkqvist, \& Österman, 2017). In the contemporary challenge of teaching online, the magnitude of work has been doubled or even more since it solely demands technological interface.

\section{Methodology}

Qualitative data was gathered for this study using exploratory methodology from sixteen universities across the country. At least one senior faculty and one member engaged in administrative responsibilities from HEC recognized universities were contacted. Quaid-e-Azam University, Bahria University, Air University, COMSATS, Fatima Jinnah Women University, Pakistan Institute of Development Economics University, PMAS-Arid Agriculture University Rawalpindi, Bahauddin Zakariya University Multan, University of Engineering Technology Lahore, University of Malakand, University of Peshawar, Institute of Management Sciences Peshawar, Riphah International University, Islamabad, Lahore University of Management Sciences, National University of Computer Engineering and Sciences-FAST and Abdul Wali Khan University Mardan were included in this research. The methods of research were In-depth interviews and Focus Discussion Groups. An Interview guide and FGD checklists were prepared as tools of study. Amid the corona pandemic yet keeping the research ethics of the domain intact; primary data, the IDIs (In-Depth Interviews) were conducted on phone calls by taking prior appointments. However, a Focus group discussion was carried out through a conference call. Since the methodology of the study was exploratory, universities were not stratified in advance. The data was post stratified later on and analyzed thematically in SPSS which is illustrated through descriptive statistical analysis in the findings section and discussed later. Keeping in view the research ethics, the names of the universities were coded to ensure confidentiality.

\section{Findings}

Keeping in view the seriousness of the situation posed by COVID-19, on March $13^{\text {th }}, 2020$ WHO declared it as a global pandemic. In the wake of the hour, the government of Pakistan declared the closure of all education institutes immediately. However, it was nearly impossible for universities and higher education institutes of the country to cease academic activities altogether. In Pakistani universities, there are generally two semesters; Spring and Fall each year with a few exceptions where the summer semester is optional in the summer break. The spring semester started in all the universities from January and February. Some had four whereas others had eight weeks of teaching. Generally, eight weeks of teaching marks the onset of midterm examination/ assessments in universities. The findings suggest that initially some universities and their respective administration communicated their faculty to continue immediately through online teaching since it was not clear whether the universities will be closed till April $5^{\text {th }}$ or will be extended. The first table is based on the status of Learning Management System, LMS in Pakistani higher education institutes. The higher education commission requested the vice chancellors of the universities to proceed with the LMS by ensuring all six key elements of the system to ensure un-interrupted learning (HEC, 2020). The data table suggest the status of LMS at the outbreak of pandemic in these sixteen universities of Pakistan.

\begin{tabular}{|c|c|c|c|c|c|c|c|c|c|c|c|c|c|c|c|c|c|c|}
\hline \multicolumn{19}{|c|}{ Codes for Universities } \\
\hline & \multirow{2}{*}{$\frac{\mathrm{A}}{\mathrm{L}}$} & B & B & C & $\mathbf{F}$ & \multirow{2}{*}{$\frac{\text { H }}{\text { IANA }}$} & \multirow{2}{*}{$\frac{\text { I }}{\text { GEN }}$} & \multirow{2}{*}{$\frac{\mathrm{K}}{\mathrm{MEN}}$} & \multirow{2}{*}{\multicolumn{2}{|c|}{$\frac{\mathrm{L} \quad \mathrm{M}}{\text { T SYST }}$}} & \multirow{2}{*}{$\frac{P}{\text { EM) }}$} & \multirow[t]{2}{*}{$\mathbf{Q}$} & \multirow{2}{*}{\multicolumn{2}{|c|}{$\mathbf{R}$}} & \multirow[t]{2}{*}{$\mathbf{U}$} & \multirow[t]{2}{*}{ W } & \multicolumn{2}{|l|}{$\mathbf{Z}$} \\
\hline & & LMS & $\overline{(\mathbf{L E} A}$ & $\overline{\text { ARNII }}$ & $\overline{\text { NG M }}$ & & & & & & & & & & & & TOTAL & \%age \\
\hline LMS- NIU & $\mathrm{N}$ & $\mathrm{N}$ & $\mathrm{N}$ & $\mathrm{N}$ & $\mathrm{N}$ & $\mathrm{N}$ & $\mathrm{N}$ & $\mathrm{Y}$ & $\mathrm{N}$ & $\mathrm{N}$ & $\mathrm{Y}$ & $\mathrm{N}$ & $\mathrm{N}$ & $\mathrm{N}$ & $\mathrm{N}$ & $\mathrm{N}$ & 2 & $12.5 \%$ \\
\hline LMS- PIU & $\mathrm{N}$ & $\mathrm{Y}$ & $\mathrm{N}$ & $\mathrm{N}$ & $\mathrm{N}$ & $\mathrm{Y}$ & $\mathrm{N}$ & $\mathrm{N}$ & $\mathrm{N}$ & $\mathrm{N}$ & $\mathrm{N}$ & $\mathrm{N}$ & $\mathrm{Y}$ & $\mathrm{Y}$ & $\mathrm{N}$ & $\mathrm{N}$ & 4 & $25.0 \%$ \\
\hline $\begin{array}{l}\text { Indigenous } \\
\text { LMS }\end{array}$ & $\mathrm{N}$ & $\mathrm{N}$ & $\mathrm{N}$ & $\mathrm{N}$ & $\mathrm{N}$ & $\mathrm{N}$ & $\mathrm{N}$ & $\mathrm{N}$ & $\mathrm{Y}$ & $\mathrm{N}$ & $\mathrm{N}$ & $\mathrm{N}$ & $\mathrm{N}$ & $\mathrm{N}$ & $\mathrm{N}$ & $\mathrm{N}$ & 1 & $6.3 \%$ \\
\hline LMS- NIP & $\mathrm{Y}$ & $\mathrm{N}$ & $\mathrm{Y}$ & $\mathrm{Y}$ & $\mathrm{Y}$ & $\mathrm{N}$ & $\mathrm{Y}$ & $\mathrm{N}$ & $\mathrm{N}$ & $\mathrm{Y}$ & $\mathrm{N}$ & $\mathrm{Y}$ & $\mathrm{N}$ & $\mathrm{N}$ & $\mathrm{Y}$ & Y & 9 & $56.3 \%$ \\
\hline In & & $-\mathrm{Pa}$ & rtiall & $y$ in & se, Nl & IP $-I$ & $t$ In & Plac & & & & & & & & & & \\
\hline & 4 & Y's O & NLII & NE PR & ESEI & NCE & befo & $\mathrm{C}$ & OVI & ID L & DCK & XDO & WN & & & & TOTAL & \%age \\
\hline Partially & $\mathrm{Y}$ & $\mathrm{N}$ & $\mathrm{Y}$ & $\mathrm{N}$ & $\mathrm{Y}$ & $\mathrm{Y}$ & $\mathrm{Y}$ & $\mathrm{N}$ & $\mathrm{N}$ & $\mathrm{N}$ & $\mathrm{Y}$ & $\mathrm{N}$ & $\mathrm{Y}$ & $\mathrm{N}$ & $\mathrm{N}$ & $\mathrm{N}$ & 7 & $43.8 \%$ \\
\hline Com! & $\mathrm{N}$ & $\mathrm{N}$ & $\mathrm{N}$ & $\mathrm{N}$ & $\mathrm{N}$ & $\mathrm{N}$ & $\mathrm{N}$ & $\mathrm{N}$ & $\mathrm{Y}$ & $\mathrm{N}$ & $\mathrm{N}$ & $\mathrm{N}$ & $\mathrm{N}$ & $\mathrm{N}$ & $\mathrm{N}$ & $\mathrm{N}$ & 1 & $6.3 \%$ \\
\hline Not at all & $\mathrm{N}$ & $\mathrm{Y}$ & $\mathrm{N}$ & Y & $\mathrm{N}$ & $\mathrm{N}$ & $\mathrm{N}$ & Y & $\mathrm{N}$ & $\mathrm{Y}$ & $\mathrm{N}$ & $\mathrm{Y}$ & $\mathrm{N}$ & $\mathrm{Y}$ & Y & Y & 8 & $\mathbf{5 0 . 0 \%}$ \\
\hline
\end{tabular}


Table No. 1: Initial Response of DAIs to COVID-19

The immediate response of the universities across the country after the sudden closure of the universities varied in terms of sectoral division of the universities and the type of degrees they were offering. Some gave summer break, some took time for online transition, and some resumed teaching in a week while a few shifted to online teaching without any interruption. The universities offering professional degrees could not switch over to the online learning mode due to the nature of the courses. Later, as per the policy devised by the Higher Education Commission of Pakistan, LMSLearning Management System was offered to the universities across Pakistan to streamline the academic process maintaining quality control. Not all the universities especially from the public sector universities could switch to this system even after ten weeks of cessation of the traditional teaching model with a few exceptions to the private universities which were already managing through LMS. Some are already striving to update their academic activities through this learning management system. Interviews from the academia have generated various responses which are organized in the current section.

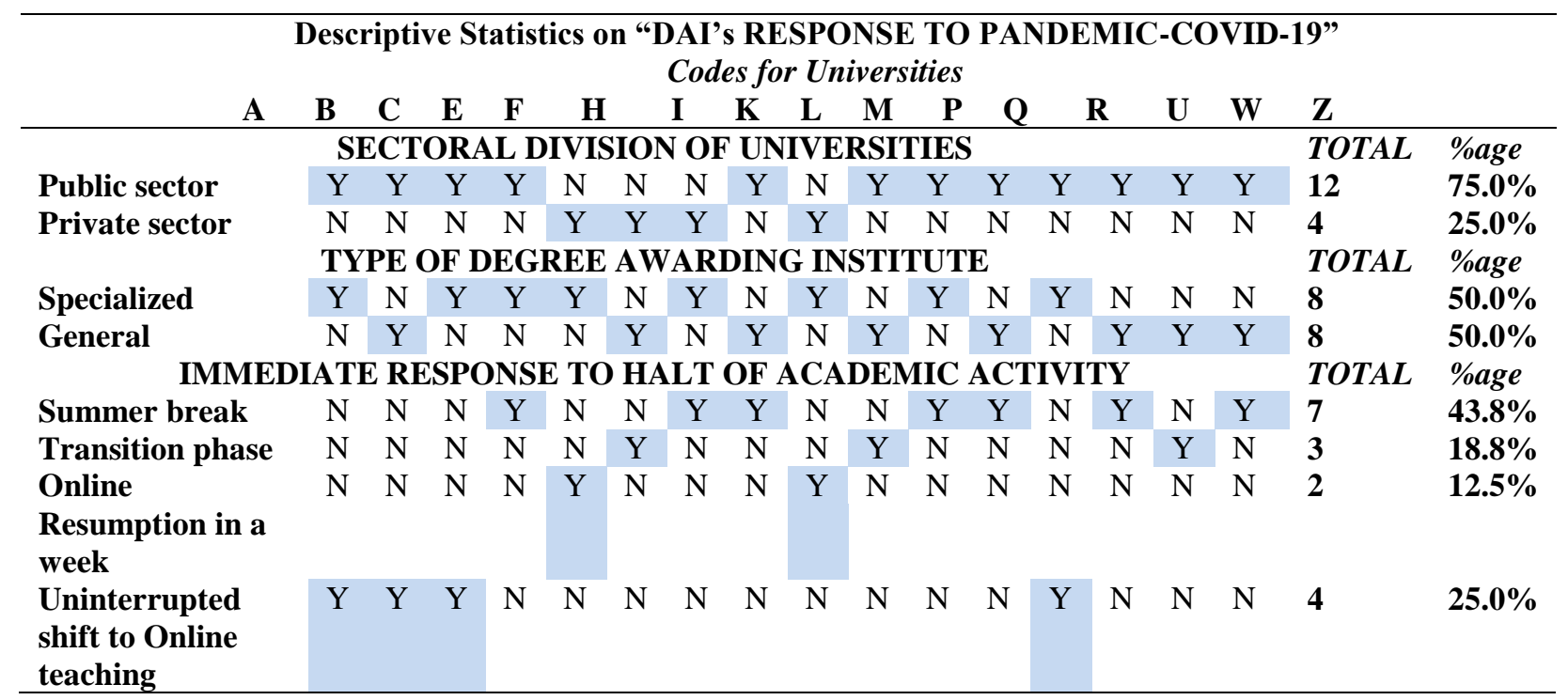

Table No. 2: Situation of Online Presence of Faculty in Universities

Majorly the response of the DAIs and their respective faculty can be divided into two cohorts; the first cohort of universities has displayed their competence in a bullish trend metaphorically which continued teaching through an immediate transition to online mode. They have experimented autonomously or as guided by the IT support teams in a couple of weeks without taking summer breaks. These universities are either from the private sector having ample resources, IT infrastructure, young and tech-savvy faculty, LMS, or alternate E-learning systems in place. In doing so, some have stressed out their faculty due to the expansive workload required for online transition, set up, and follow certain academic SOPs. They generally have multiple but smaller campuses and serve a certain upper-middle and higher class of the society. Their graduates are generally produced for the international market and result in brain drain. The status of online presence of the faculty amongst these universities is presented in table 2 .

\begin{tabular}{|c|c|c|c|c|c|c|c|c|c|c|c|c|c|c|c|c|c|c|}
\hline \multicolumn{19}{|c|}{$\begin{array}{l}\text { "Virtual Tools used for Online Classes" } \\
\text { Codes for Universities }\end{array}$} \\
\hline & $\mathbf{A}$ & $\mathbf{I}$ & B & $\mathbf{C}$ & $\mathbf{E}$ & $\mathbf{F}$ & $\mathbf{H}$ & I & $\mathbf{K}$ & $\mathbf{L}$ & & M & $\mathbf{P}$ & $\mathbf{Q}$ & $\mathbf{R}$ & $\mathbf{U}$ & $\mathbf{W}$ & \\
\hline \multicolumn{15}{|c|}{ TOOLS USED IN ONLINE TRANSITION } & & & TOTAL & \%age \\
\hline GM & $\mathrm{N}$ & $\mathrm{N}$ & $\mathrm{N}$ & $\mathrm{N}$ & $\mathrm{N}$ & $\mathrm{N}$ & $\mathrm{N}$ & $\mathrm{N}$ & $\mathrm{N}$ & $\mathrm{N}$ & $\mathrm{N}$ & $\mathrm{N}$ & $\mathrm{N}$ & Y & $\mathrm{N}$ & $\mathrm{N}$ & 1 & $6.3 \%$ \\
\hline MS & $\mathrm{N}$ & $\mathrm{N}$ & $\mathrm{N}$ & $\mathrm{N}$ & $\mathrm{N}$ & $\mathrm{N}$ & $\mathrm{N}$ & $\mathrm{N}$ & $\mathrm{N}$ & $\mathrm{N}$ & $\mathrm{N}$ & $\mathrm{Y}$ & $\mathrm{N}$ & $\mathrm{N}$ & $\mathrm{N}$ & $\mathrm{N}$ & 1 & $6.3 \%$ \\
\hline WA & $\mathrm{N}$ & $\mathrm{N}$ & $\mathrm{N}$ & Y & $\mathrm{N}$ & $Y$ & $\mathrm{~N}$ & $\mathrm{Y}$ & $\mathrm{N}$ & $\mathrm{N}$ & $\mathrm{N}$ & $\mathrm{N}$ & $\mathrm{N}$ & $\mathrm{N}$ & $\mathrm{N}$ & $\mathrm{Y}$ & 4 & $25.0 \%$ \\
\hline $\begin{array}{l}\text { GM, GC and } \\
\text { LMS }\end{array}$ & $\mathrm{N}$ & $\mathrm{N}$ & $\mathrm{N}$ & $\mathrm{N}$ & $\mathrm{N}$ & $\mathrm{N}$ & $\mathrm{Y}$ & $\mathrm{N}$ & $\mathrm{N}$ & $\mathrm{N}$ & $\mathrm{N}$ & $\mathrm{N}$ & $\mathrm{N}$ & $\mathrm{N}$ & $\mathrm{N}$ & $\mathrm{N}$ & 1 & $6.3 \%$ \\
\hline ZM and LMS & $\mathrm{N}$ & $\mathrm{N}$ & $\mathrm{N}$ & $\mathrm{N}$ & $\mathrm{N}$ & $\mathrm{N}$ & $\mathrm{N}$ & $\mathrm{N}$ & $\mathrm{Y}$ & $\mathrm{N}$ & $\mathrm{N}$ & $\mathrm{N}$ & $\mathrm{N}$ & $\mathrm{N}$ & $\mathrm{N}$ & $\mathrm{N}$ & 1 & $6.3 \%$ \\
\hline ZM and WA & $\mathrm{N}$ & $\mathrm{Y}$ & $\mathrm{Y}$ & $\mathrm{N}$ & $\mathrm{N}$ & $\mathrm{N}$ & $\mathrm{N}$ & $\mathrm{N}$ & $\mathrm{N}$ & $\mathrm{Y}$ & $\mathrm{N}$ & $\mathrm{N}$ & $\mathrm{N}$ & $\mathrm{N}$ & $\mathrm{N}$ & $\mathrm{N}$ & 3 & $18.8 \%$ \\
\hline ZM and GM & $\mathrm{N}$ & $\mathrm{N}$ & $\mathrm{N}$ & $\mathrm{N}$ & $Y$ & $\mathrm{~N}$ & $\mathrm{~N}$ & $\mathrm{~N}$ & $\mathrm{~N}$ & $\mathrm{~N}$ & $\mathrm{Y}$ & $\mathrm{N}$ & $\mathrm{N}$ & $\mathrm{N}$ & $\mathrm{N}$ & $\mathrm{N}$ & 2 & $12.5 \%$ \\
\hline ZM, WA and & $\mathrm{N}$ & $\mathrm{N}$ & $\mathrm{N}$ & $\mathrm{N}$ & $\mathrm{N}$ & $\mathrm{N}$ & $\mathrm{N}$ & $\mathrm{N}$ & $\mathrm{N}$ & $\mathrm{N}$ & $\mathrm{N}$ & $\mathrm{N}$ & $\mathrm{Y}$ & $\mathrm{N}$ & $\mathrm{N}$ & $\mathrm{N}$ & 1 & $6.3 \%$ \\
\hline
\end{tabular}


FB

$\begin{array}{lllllllllllllllllllll}\text { ZM and GC } & \mathrm{Y} & \mathrm{N} & \mathrm{N} & \mathrm{N} & \mathrm{N} & \mathrm{N} & \mathrm{N} & \mathrm{N} & \mathrm{N} & \mathrm{N} & \mathrm{N} & \mathrm{N} & \mathrm{N} & \mathrm{N} & \mathrm{Y} & \mathrm{N} & \mathbf{2} & & \mathbf{1 2 . 5 \%}\end{array}$

GM- Google Meet up, MS-Microsoft Teams, WA-What's App, GC-Google Classroom, ZM-Zoom, FB-Face Book

\begin{tabular}{|c|c|c|c|c|c|c|c|c|c|c|c|c|c|c|c|c|c|c|}
\hline & TO & OL & US & ED 1 & $\mathbf{N ~ C ~}$ & MF & LE' & E O & LII & E T & AC & HIN & & & & & TOTAL & \%age \\
\hline ZM & $\mathrm{Y}$ & $\mathrm{N}$ & $\mathrm{N}$ & $\mathrm{N}$ & $\mathrm{N}$ & $\mathrm{N}$ & $\mathrm{N}$ & $\mathrm{N}$ & $\mathrm{N}$ & $\mathrm{N}$ & $\mathrm{N}$ & $\mathrm{N}$ & $\mathrm{N}$ & $\mathrm{N}$ & $\mathrm{N}$ & $\mathrm{N}$ & 1 & $6.3 \%$ \\
\hline GC & $\mathrm{N}$ & $\mathrm{N}$ & $\mathrm{N}$ & $\mathrm{N}$ & $\mathrm{N}$ & $\mathrm{N}$ & $\mathrm{N}$ & $\mathrm{N}$ & $\mathrm{N}$ & $\mathrm{N}$ & $\mathrm{N}$ & $\mathrm{N}$ & $\mathrm{N}$ & $\mathrm{N}$ & $\mathrm{Y}$ & $\mathrm{N}$ & 1 & $6.3 \%$ \\
\hline LMS & $\mathrm{N}$ & $\mathrm{Y}$ & $\mathrm{N}$ & $\mathrm{N}$ & $\mathrm{N}$ & $\mathrm{N}$ & $\mathrm{N}$ & $\mathrm{Y}$ & $\mathrm{N}$ & $\mathrm{Y}$ & $\mathrm{N}$ & $\mathrm{N}$ & $\mathrm{Y}$ & $\mathrm{N}$ & $\mathrm{N}$ & $\mathrm{N}$ & 4 & $25.0 \%$ \\
\hline MS & $\mathrm{N}$ & $\mathrm{N}$ & Y & $\mathrm{Y}$ & $\mathrm{N}$ & $\mathrm{N}$ & $\mathrm{N}$ & $\mathrm{N}$ & $\mathrm{N}$ & $\mathrm{N}$ & $\mathrm{Y}$ & $\mathrm{N}$ & $\mathrm{N}$ & $\mathrm{N}$ & $\mathrm{N}$ & $\mathrm{N}$ & 3 & $18.8 \%$ \\
\hline GM \& LMS & $\mathrm{N}$ & $\mathrm{N}$ & $\mathrm{N}$ & $\mathrm{N}$ & $\mathrm{N}$ & $\mathrm{N}$ & $\mathrm{N}$ & $\mathrm{N}$ & $\mathrm{N}$ & $\mathrm{N}$ & $\mathrm{N}$ & $\mathrm{N}$ & $\mathrm{N}$ & $\mathrm{Y}$ & $\mathrm{N}$ & $\mathrm{N}$ & 1 & $6.3 \%$ \\
\hline $\begin{array}{l}\text { GM, GC \& } \\
\text { LMS }\end{array}$ & $\mathrm{N}$ & $\mathrm{N}$ & $\mathrm{N}$ & $\mathrm{N}$ & $\mathrm{N}$ & $\mathrm{N}$ & $\mathrm{Y}$ & $\mathrm{N}$ & $\mathrm{N}$ & $\mathrm{N}$ & $\mathrm{N}$ & $\mathrm{N}$ & $\mathrm{N}$ & $\mathrm{N}$ & $\mathrm{N}$ & $\mathrm{N}$ & 1 & $6.3 \%$ \\
\hline ZM \& LMS & $\mathrm{N}$ & $\mathrm{N}$ & $\mathrm{N}$ & $\mathrm{N}$ & $\mathrm{N}$ & $\mathrm{N}$ & $\mathrm{N}$ & $\mathrm{N}$ & Y & $\mathrm{N}$ & $\mathrm{N}$ & $\mathrm{N}$ & $\mathrm{N}$ & $\mathrm{N}$ & $\mathrm{N}$ & $\mathrm{N}$ & 1 & $6.3 \%$ \\
\hline ZM \& MS & $\mathrm{N}$ & $\mathrm{N}$ & $\mathrm{N}$ & $\mathrm{N}$ & Y & $\mathrm{N}$ & $\mathrm{N}$ & $\mathrm{N}$ & $\mathrm{N}$ & $\mathrm{N}$ & $\mathrm{N}$ & $\mathrm{N}$ & $\mathrm{N}$ & $\mathrm{N}$ & $\mathrm{N}$ & $\mathrm{N}$ & 1 & $6.3 \%$ \\
\hline WA \& MM & $\mathrm{N}$ & $\mathrm{N}$ & $\mathrm{N}$ & $\mathrm{N}$ & $\mathrm{N}$ & Y & $\mathrm{N}$ & $\mathrm{N}$ & $\mathrm{N}$ & $\mathrm{N}$ & $\mathrm{N}$ & $\mathrm{Y}$ & $\mathrm{N}$ & $\mathrm{N}$ & $\mathrm{N}$ & Y & 3 & $18.8 \%$ \\
\hline
\end{tabular}

\section{Table No. 3: Virtual Tools engaged for Online Teaching}

The $2^{\text {nd }}$ cohort of universities acts in a bullish manner by giving a semester break to their students after the initial two weeks of transition to online teaching. Most of these universities were from the private sector. The decision was made keeping in view the university's mandate, IT infrastructure and support system, students' community, and online readiness for teaching. The break commenced from April and lasted till May $31^{\text {st }}$. Most of the universities halted the academic process instead of a summer break and continued preparing for the transition to online mode meanwhile. It is expected that these universities have meanwhile completed their work to shift to a new online teaching mechanism from June 2020. These universities have been tuned to traditionalism. They have a bureaucratic education system, are often prey to red tape-ism, have standardized SOPs, and follow PEPRA rules strictly. Their adaptability to change is gradual and slow. Ironically, they follow a bearish trend since they cover a larger segment of society in terms of diversity, ethnicities, and student enrolment. They usually serve a clientele across all socio-economic classes but specifically the lower and middle class and eventually serve Pakistan since their graduates are produced for the local job market.

\section{Discussion}

Technology is pervasively used in the domain of academics throughout the world. However, in past two decades, the pace of transformation has increased. The countries and institutions which display an adaptive approach are leading in the field of academics; however, the laggards are the slow adapters. A joint report of the Euro fund and ILO based on findings and surveys from 15 European countries have synthesized the effects of ICT mobile networks and tele-work (Eurofound \& ILO, 2017). The potential benefits of technology (flexibility, autonomy, cost-saving, and lack of commutation) are evident in the containment of epidemiology like COVID-19 (García-González, Torrano, \& GarcíaGonzález, 2020). Online teaching is not an optional mode of teaching any more in Pakistan. Besides the COVID-19 pandemic that has shaken the academic world all of a sudden, several such recent events in Pakistan were already compelling us to evolve new modes of teaching for sustainable education. The virtual tools used by the universities for transition to online teaching are numerous. As informed by the faculty of the universities approached, these tools were experimented by the faculty and the IT support teams which are presented in table 3 . To run the academic cycle uninterruptedly, it is the need of the hour to develop a sustainable learning model. The recent nationwide lockdown was triggered due to a natural pandemic; however, certain nationwide and local lockdowns by political parties and clerics were already compelling the universities especially from the twin cities to adapt to new teaching methodologies that could allow the universities to follow the academic calendar.

Keeping the Students Onboard; The biggest challenge in determining online readiness is to ensure the students readiness for online mode of learning by keeping the students on-board. Reaching out to the students appeared as a major challenge to the public sector universities of Pakistan which have a larger mandate and quota of students from all across the country. In some universities, it was the responsibility of the university, in others it was the students; responsibility as presented in table 4. Online teaching has been termed as a 'grand experiment' in comparison with face to face teaching in a 
recent article (Zimmerman, 2020). However, as long as the faculty is not acquainted with the requisite skills and resultantly not contented with their teaching, they can never satisfy the yearning thirst of their students. The amounting techno-stress is a major factor in the performance of teachers in pacing up with the standards required in online teaching. Varieties of teaching experiments have been carried out in the past 2-3 months by the universities and faculty to engage the students. Since there were no indigenous online teaching models in place, Google classrooms, Microsoft Team, Zoom, Google Meet, Skype, What's App and Face book were used by the faculty members initially from two weeks and up to 2 months. Some universities have adopted LMS whereas the rest have switched to Microsoft Teams for regular online classes with a few exceptions which have given autonomy to the teachers to use whichever tool appropriate for this semester.

Examination and Assessments: Most of the universities had not conducted their midterm examinations by the time of closure and there was no system of online examination in place. The universities are now preparing for the online exams and assessments of the students from JuneSeptember depending upon their revised academic calendar. In most of the universities approached a, the faculty is supposed to prepare two kinds of papers; one MCQ or viva based online and the other on the regular examination system of the respective university. Some universities have allowed the faculty to give multiple chances for appearance in examination to students from remote areas. Most of the universities have directed the faculty to mark the Mid-term Exams through additional assignments. The steps taken by different universities for assessment of mid-term and final term examination are demonstrated in table 4. Multiple exam types and examining each student individually based upon their availability are again going to stress the faculty and stretch the amount of time for assessments.

\begin{tabular}{|c|c|c|c|c|c|c|c|c|c|c|c|c|c|c|c|c|c|c|}
\hline & \multicolumn{18}{|c|}{$\begin{array}{c}\text { Descriptive Statistics on "Engaging and Reaching out to Students during Pandemic" } \\
\text { Codes for Universities }\end{array}$} \\
\hline & $\mathbf{A}$ & $\mathbf{B}$ & $\mathbf{E}$ & $\mathbf{F}$ & $\mathbf{H}$ & $\mathbf{I}$ & $\mathbf{K}$ & $\mathbf{L}$ & $\mathbf{M}$ & $\mathbf{P}$ & $\mathbf{Q}$ & $\mathbf{R}$ & $\mathbf{U}$ & $\mathbf{W}$ & $\mathbf{Z}$ & & & \\
\hline \multicolumn{19}{|c|}{ MODES OF MID TERM ASSESSMENT } \\
\hline OE & $\mathrm{N}$ & $\mathrm{N}$ & $\mathrm{N}$ & $\mathrm{N}$ & $\mathrm{N}$ & $\mathrm{N}$ & $\mathrm{N}$ & $\mathrm{N}$ & $\mathrm{Y}$ & $\mathrm{N}$ & $\mathrm{N}$ & $\mathrm{N}$ & $\mathrm{N}$ & $\mathrm{N}$ & $\mathrm{N}$ & $\mathrm{N}$ & 1 & $6.3 \%$ \\
\hline $\mathbf{A A}$ & $\mathrm{N}$ & $\mathrm{Y}$ & $\mathrm{Y}$ & $\mathrm{N}$ & $\mathrm{Y}$ & $\mathrm{N}$ & $\mathrm{N}$ & Y & $\mathrm{N}$ & $\mathrm{Y}$ & $\mathrm{N}$ & $\mathrm{Y}$ & $\mathrm{Y}$ & $\mathrm{N}$ & $\mathrm{N}$ & $\mathrm{N}$ & 7 & $43.8 \%$ \\
\hline UD & Y & $\mathrm{N}$ & $\mathrm{N}$ & $\mathrm{Y}$ & $\mathrm{N}$ & $\mathrm{N}$ & $\mathrm{N}$ & $\mathrm{N}$ & $\mathrm{N}$ & $\mathrm{N}$ & $\mathrm{Y}$ & $\mathrm{N}$ & $\mathrm{N}$ & $\mathrm{Y}$ & $\mathrm{Y}$ & $\mathrm{Y}$ & 6 & $37.5 \%$ \\
\hline $\begin{array}{l}\mathbf{A A} \\
\text { \&OE }\end{array}$ & $\mathrm{N}$ & $\mathrm{N}$ & $\mathrm{N}$ & $\mathrm{N}$ & $\mathrm{N}$ & Y & $\mathrm{N}$ & $\mathrm{N}$ & $\mathrm{N}$ & $\mathrm{N}$ & $\mathrm{N}$ & $\mathrm{N}$ & $\mathrm{N}$ & $\mathrm{N}$ & $\mathrm{N}$ & $\mathrm{N}$ & 1 & $6.3 \%$ \\
\hline $\begin{array}{l}\text { AA, PJ } \\
\text { \& FA }\end{array}$ & $\mathrm{N}$ & $\mathrm{N}$ & $\mathrm{N}$ & $\mathrm{N}$ & $\mathrm{N}$ & $\mathrm{N}$ & $\mathrm{Y}$ & $\mathrm{N}$ & $\mathrm{N}$ & $\mathrm{N}$ & $\mathrm{N}$ & $\mathrm{N}$ & $\mathrm{N}$ & $\mathrm{N}$ & $\mathrm{N}$ & $\mathrm{N}$ & 1 & $6.3 \%$ \\
\hline \multicolumn{19}{|c|}{ OE-Online Exam, AA-Additional Assignments, UD-Undecided, PJ-Project based, FA-Faculty's Autonomy } \\
\hline & & REACH & I OU' & T TO & STU & EN & S F & RON & I RE & MO & TE & ARE & AS & & & & TOTAL & \%age \\
\hline ROS & Y & $\mathrm{N}$ & $\mathrm{N}$ & $\mathrm{Y}$ & $\mathrm{N}$ & $\mathrm{Y}$ & $\mathrm{N}$ & $\mathrm{Y}$ & $\mathrm{N}$ & $\mathrm{N}$ & $\mathrm{N}$ & $\mathrm{N}$ & $\mathrm{Y}$ & $\mathrm{N}$ & $\mathrm{Y}$ & $\mathrm{Y}$ & 7 & $43.8 \%$ \\
\hline $\mathrm{Cr}$ & $\mathrm{N}$ & $\mathrm{Y}$ & $\mathrm{N}$ & $\mathrm{N}$ & $\mathrm{Y}$ & $\mathrm{N}$ & $\mathrm{N}$ & $\mathrm{N}$ & $\mathrm{Y}$ & $\mathrm{N}$ & $\mathrm{Y}$ & $\mathrm{N}$ & $\mathrm{N}$ & $\mathrm{N}$ & $\mathrm{N}$ & $\mathrm{N}$ & 4 & $25.0 \%$ \\
\hline FM & $\mathrm{N}$ & $\mathrm{N}$ & $\mathrm{N}$ & $\mathrm{N}$ & $\mathrm{N}$ & $\mathrm{N}$ & $\mathrm{N}$ & $\mathrm{N}$ & $\mathrm{N}$ & $\mathrm{N}$ & $\mathrm{N}$ & $\mathrm{Y}$ & $\mathrm{N}$ & $\mathrm{N}$ & $\mathrm{N}$ & $\mathrm{N}$ & 1 & $6.3 \%$ \\
\hline AS & $\mathrm{N}$ & $\mathrm{N}$ & Y & $\mathrm{N}$ & $\mathrm{N}$ & $\mathrm{N}$ & $\mathrm{N}$ & $\mathrm{N}$ & $\mathrm{N}$ & $\mathrm{Y}$ & $\mathrm{N}$ & $\mathrm{N}$ & $\mathrm{N}$ & Y & $\mathrm{N}$ & $\mathrm{N}$ & 3 & $18.8 \%$ \\
\hline $\begin{array}{l}\text { FM \& } \\
\text { AS }\end{array}$ & $\mathrm{N}$ & $\mathrm{N}$ & $\mathrm{N}$ & $\mathrm{N}$ & $\mathrm{N}$ & $\mathrm{Y}$ & $\mathrm{N}$ & $\mathrm{N}$ & $\mathrm{N}$ & $\mathrm{N}$ & $\mathrm{N}$ & $\mathrm{N}$ & $\mathrm{N}$ & $\mathrm{N}$ & $\mathrm{N}$ & $\mathrm{N}$ & 1 & $6.3 \%$ \\
\hline \multicolumn{19}{|c|}{ ROS-Responsibility Of Student, Cr-Coordinator, FM-Faculty Member, AS-Academic Section } \\
\hline & & & & MO & DE & OF & INA & $\mathbf{L} \mathbf{E}$ & XAN & & & & & & & & TOTAL & \%age \\
\hline OE & Y & $\mathrm{N}$ & Y & $\mathrm{N}$ & $\mathrm{Y}$ & Y & $\mathrm{N}$ & $\mathrm{N}$ & Y & $\mathrm{Y}$ & $\mathrm{N}$ & $\mathrm{N}$ & $\mathrm{Y}$ & $\mathrm{N}$ & $\mathrm{N}$ & $\mathrm{N}$ & 7 & $43.8 \%$ \\
\hline SWD & $\mathrm{N}$ & $\mathrm{N}$ & $\mathrm{N}$ & $\mathrm{Y}$ & $\mathrm{N}$ & $\mathrm{N}$ & $\mathrm{N}$ & $\mathrm{N}$ & $\mathrm{N}$ & $\mathrm{N}$ & $\mathrm{N}$ & $\mathrm{N}$ & $\mathrm{N}$ & $\mathrm{N}$ & $\mathrm{N}$ & $\mathrm{N}$ & 1 & $6.3 \%$ \\
\hline UD & $\mathrm{N}$ & $\mathrm{N}$ & $\mathrm{N}$ & $\mathrm{N}$ & $\mathrm{N}$ & $\mathrm{N}$ & $\mathrm{N}$ & $\mathrm{Y}$ & $\mathrm{N}$ & $\mathrm{N}$ & $\mathrm{N}$ & $\mathrm{N}$ & $\mathrm{N}$ & $\mathrm{Y}$ & $\mathrm{Y}$ & $\mathrm{N}$ & 3 & $18.8 \%$ \\
\hline UDD & $\mathrm{N}$ & Y & $\mathrm{N}$ & $\mathrm{N}$ & $\mathrm{N}$ & $\mathrm{N}$ & $\mathrm{N}$ & $\mathrm{N}$ & $\mathrm{N}$ & $\mathrm{N}$ & $\mathrm{Y}$ & $\mathrm{N}$ & $\mathrm{N}$ & $\mathrm{N}$ & $\mathrm{N}$ & $\mathrm{Y}$ & 3 & $18.8 \%$ \\
\hline FA\&AA & $\mathrm{N}$ & $\mathrm{N}$ & $\mathrm{N}$ & $\mathrm{N}$ & $\mathrm{N}$ & $\mathrm{N}$ & Y & $\mathrm{N}$ & $\mathrm{N}$ & $\mathrm{N}$ & $\mathrm{N}$ & $\mathrm{N}$ & $\mathrm{N}$ & $\mathrm{N}$ & $\mathrm{N}$ & $\mathrm{N}$ & 1 & $6.3 \%$ \\
\hline $\begin{array}{l}\text { OE, IS } \\
\text { \& FA }\end{array}$ & $\mathrm{N}$ & $\mathrm{N}$ & $\mathrm{N}$ & $\mathrm{N}$ & $\mathrm{N}$ & $\mathrm{N}$ & $\mathrm{N}$ & $\mathrm{N}$ & $\mathrm{N}$ & $\mathrm{N}$ & $\mathrm{N}$ & $\mathrm{Y}$ & $\mathrm{N}$ & $\mathrm{N}$ & $\mathrm{N}$ & $\mathrm{N}$ & 1 & $6.3 \%$ \\
\hline $\begin{array}{l}\text { OE-Onli } \\
\text { Autonom }\end{array}$ & . & $\begin{array}{l}m, S V \\
\text { Addit }\end{array}$ & $\begin{array}{l}\text { WD- } \\
\text { tiond }\end{array}$ & Seme & 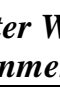 & 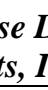 & cisic & , & D- $U$ & n & $\cdot$ & $\boldsymbol{U}$ & $D D-$ & $U$ & & & 4 & 's \\
\hline
\end{tabular}

Table No. 4: Modes of Students 'engagement and reaching out

Sudden Shift to Online Teaching; The participants shared how suddenness of closure left them bewildered initially. Since the faculty was approached by the students and not all the universities' administration offered solutions or assisted the faculty in online teaching. The predominant mode of 
teaching in the universities across Pakistan was instructor-centred, face to face mode of teaching. Online teaching does not only take into account the readiness indicators of the universities in maintaining quality control, but also demands an entire paradigm shift in which the entire student community, their parents, mentors, academia, university administration, public-private partnerships especially with telecommunication industries and the state need to be an equal stakeholder and play its relevant part. The higher education commission has formulated a well-designed policy document in this regard, but the practical implementation of the policy takes both time and resources. Most of all, the willingness to overcome fear and adapt to the relevant technology will eventually ensure the online readiness. Online readiness of the faculty is generally hampered by personal factors which lead to techno-stress.

Situation at Home; Teachers shared that the situation at home often does not allow them to participate in the lessons timely. The idea of working from home is pretty new in Pakistan. People were only aware of this phenomenon relating to the software industry. Apart from that, the working ethics have neither been fully established nor followed in Pakistan. Working or teaching from home needs to be balanced to maintain a work-life balance, kind of supervision, and time management (Messenger \& Gschwind, 2016)\& (Xie, Ma, Zhou, \& Tang, 2018). The situation at home for both faculty and student matters in determining their regularity in online classes. The findings from the IDIs conducted with the faculty and administration of the universities suggest that besides all the efforts made on part of the faculty, absenteesim persisted as reflected by the attendance of students in online classes in table 5 .

Absenteeism; Losing many students is a major disadvantage that runs the risk in online teaching. Absenteeism was the initial issue faced by the faculty in ensuring the online attendance of the students which can be resolved through LMS. The reasons are lack of connection and signals, accessibility, login issues, and voice quality. Universities where multiple modes of teaching are allowed also to ensure that their faculty keeps records of the students attending classes online and only those students can be excused who genuinely belong to the remote areas. In those cases, many universities are facilitating both the teachers and students through sharing the video lectures and course material on CDs, DVDs and USBs, but the driving factor is the students' motivation and the efforts of the faculty in taking them on board alongside.

\begin{tabular}{|c|c|c|c|c|c|c|c|c|c|c|c|c|c|c|c|c|c|c|}
\hline \multicolumn{19}{|c|}{ Codes for Universities } \\
\hline $\mathbf{C}$ & $\mathbf{E}$ & $\mathbf{F}$ & $\mathbf{I}$ & $\mathbf{K}$ & $\mathbf{L}$ & $\mathbf{M}$ & $\mathbf{P} \mathbf{Q}$ & & $\mathbf{U}$ & $\mathbf{W}$ & $\mathbf{Z}$ & & & & & & & \\
\hline \multicolumn{17}{|c|}{ STUDENTS' ATTENDANCE DURING ONLINE CLASSES } & TOTAL & \%age \\
\hline Between 41-60\% & $\mathrm{N}$ & $\mathrm{N}$ & $\mathrm{N}$ & $\mathrm{N}$ & $\mathrm{N}$ & $\mathrm{N}$ & $\mathrm{N}$ & $\mathrm{N}$ & $\mathrm{N}$ & $\mathrm{N}$ & $\mathrm{N}$ & $\mathrm{N}$ & $\mathrm{N}$ & $\mathrm{N}$ & $\mathrm{Y}$ & $\mathrm{Y}$ & 2 & $12.5 \%$ \\
\hline \multirow{2}{*}{$\begin{array}{l}\text { Between 61-80\% } \\
\text { Above 81\% }\end{array}$} & $\mathrm{N}$ & $\mathrm{N}$ & $\mathrm{N}$ & $\mathrm{Y}$ & $\mathrm{N}$ & $\mathrm{N}$ & Y & Y & $\mathrm{N}$ & $\mathrm{N}$ & $\mathrm{N}$ & Y & $\mathrm{Y}$ & Y & $\mathrm{N}$ & $\mathrm{N}$ & 6 & $37.5 \%$ \\
\hline & Y & Y & Y & $\mathrm{N}$ & $\mathrm{Y}$ & Y & $\mathrm{N}$ & $\mathrm{N}$ & Y & Y & Y & $\mathrm{N}$ & $\mathrm{N}$ & $\mathrm{N}$ & $\mathrm{N}$ & $\mathrm{N}$ & 8 & $\mathbf{5 0 . 0 \%}$ \\
\hline \multicolumn{17}{|c|}{ FACULTY ADAPTATION TO ONLINE TEACHING } & TOTAL & \%age \\
\hline Partial & $\mathrm{N}$ & Y & $\mathrm{N}$ & $\mathrm{Y}$ & $\mathrm{Y}$ & Y & $\mathrm{N}$ & $\mathrm{Y}$ & Y & Y & Y & Y & $\mathrm{Y}$ & $\mathrm{N}$ & $\mathrm{Y}$ & $\mathrm{Y}$ & 12 & $75.0 \%$ \\
\hline Complete & Y & $\mathrm{N}$ & $\mathrm{Y}$ & $\mathrm{N}$ & $\mathrm{N}$ & $\mathrm{N}$ & $\mathrm{Y}$ & $\mathrm{N}$ & $\mathrm{N}$ & $\mathrm{N}$ & $\mathrm{N}$ & $\mathrm{N}$ & $\mathrm{N}$ & $\mathrm{Y}$ & $\mathrm{N}$ & $\mathrm{N}$ & 4 & $25.0 \%$ \\
\hline
\end{tabular}

Table No. 5: Students' attendance and Faculty's Adaptation to Online Teaching

Amount of Work; Almost all the universities are revising their course curriculum and contents which can be efficiently delivered online. But during the transition phase; mid of March- June, the amount of work doubled or multiplied even more due to the multiplicity of tasks as evident from universities from cohort 1. It was found in a longitudinal case study based on teaching online (discussions, emails, and assignments) that one credit or one hour of teaching face to face is comparable to 3.5 to 7 hours of teaching online classes (Lazarus, 2003). However, in universities where the classes are commencing from June and the faculty's readiness can still not be ensured since most have not conducted training and the work strain is yet to appear. In terms of the sectoral division of the universities, the public sector faculty complained more of the amounting work load emerged out of online teaching as compared to the private sector universities. One major reason behind it was that the faculty from the private sector universities was already well equipped and well versed with the technology and paid accordingly, whereas most of the faculty from the public sector university was not using much of the audio-visual teaching aids and were already burdened with the credit hours which could be a probable reason in the lack of efficient adaptation to the online teaching.

Work Load and Time; Workload, unrealistic work demands, interruptions and time pressures are accounted for major work-related stressors by both Health and Safety Executive (HSE) and Charted 
Institute of Personnel Development (CIPD) (Health and Safety Executive, 2019) \& (Chartered Institute of Personnel Development, 2020). Those who are working are hard shared that it takes them 12-14 hours to complete their teaching assignments and related tasks at home. Once the boundaries between work and personal life have trespassed, techno-stressors emerge such as emotional stress and high exhaustion levels (European Agency for Safety and Health at Work, 2019). Some universities and their administrations do not hesitate to contact their employees even after working hours which keeps the faculty stressed out throughout the day. The family lives have been seriously disturbed. The line between working hours and leisure time has got so vague that it continues to strain them. The faculty's response from the FGD highlights that the unrealistic workload assigned to the faculty was stressing them out. In some public sector universities, the lecturers and assistant professors were assigned 14 and 12 credit hours respectively. According to those respondents, it was humanly impossible to prepare course slides and presentations for 4-5 courses in a week. In trying to do so, they complained that they were spending 12-14 hours at least per day on working from home which had taken over their family time. Table 6 is based on the on ground factors determining the online readiness of the faculty from these universities. Overlapping in both spheres consequently becomes an obstacle when one faces issues in maintaining a balance between workload family life and eventually results in a stressor (O'Laughlin \& Bischoff, 2005) \& (Olson-Buchanan \& Boswell, 2006).

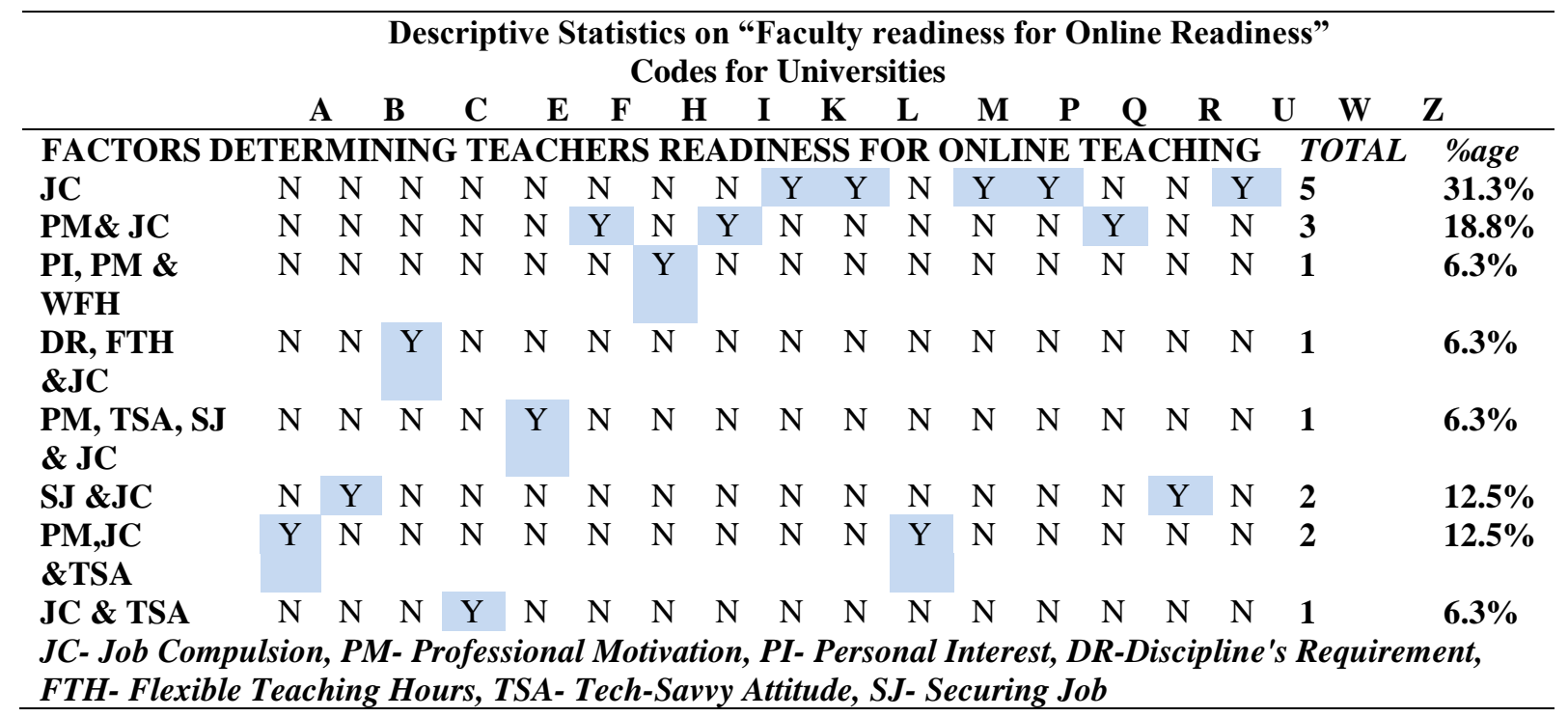

Table No. 6: Factors determining the Faculty's Readiness for Online Readiness

Governance; The data gathered from IDIs with the administration suggests that they considered online learning as an efficient tool of governance and can ensure transparency. Alongside, some university administrators complained that even now, not all the faculty is ready to perform their duties efficiently. It was gathered that most of the faculty was not intentionally reluctant in using technology but they had issues in coping up. Dr. Sarah Pickup in her recent article published in April (2020) cites that in the United Kingdom, above half a million employees are caught with absenteeism since they complain of work-related anxiety, stress, and depression (ASD). Many of them have presented the students' concerns as excuses for not teaching online or have complained of the non-availability of the internet and gadgets. But they except that the issues about governance can be completely solved once there is transparency in the system. Neither students nor teachers can manipulate the system once LMS gets fully functional.

Fear of Technology, Lack of facilities \& Lock Down; A study by Mitchell et al., (2015) suggests that resistance in faculty adaptation to online teaching includes personal factors such as cultural assumptions and values, fear (of the unknown, loss, failure), fear of disruption of interpersonal relationships and concerns about the external impact of change (Self \& Schraeder, 2009)\& (Yukl, 2006). The most evident and generic issues faced and reported by the faculty are that some are devoid of the android phones and laptops, internet connection, power disruption, camera and voice quality, camera consciousness, fear of technology, fear of making mistakes and being ridiculed, even harassment and humiliation from the students end, overburden due to multiplication of work, lack of 
observance of office hours and working ethics from the administration. Also, due to the sudden closure of universities and vacation of campuses, most of the faculty have left for their hometowns. Later, the imposition of lockdown in the country worsened the situation of inter and intra city travelling and many faculty members got stuck.

Employment Insecurity; There is another factor which is evident from the current surveys conducted by the universities amongst their students. A large number of students are not interested to continue with online education and want their current and next semesters frozen. The lack of online readiness from the students is also stressing the faculty since it may cause a heavy burden on the finances of the universities and put the jobs of the faculty at stake eventually. Also, the fear of performing inefficiently in the 'new normal' online mode, appeared to be the dominant factor raising employment insecurity in the faculty specially from the private sector universities, contractual and Tenure Tracked staff in both public and private sector universities. The following table is based on the empirical findings on factors determining online readiness of the faculty.

Parental pressure on the feasibility of online teaching is another factor that has serious implications. Besides understanding that online teaching is the need of the hour in pandemic circumstances, not an imposition made by the university otherwise, they are not ready to accept this idea. The major complaint that they present is that students do not have internet connectivity or tools. Keeping this concern in view, neither the university nor the faculty can put such a huge investment to support the students. Both students and faculty need to arrange it through their means. The higher education commission should also bring forth such student and parental alerts about online education initiatives to make them realize the importance of staying connected through online education and one never knows the implications and span of COVID-19 and its stretch.

A consequence of lack of control over technology; Some faculty members have faced serious implications of online teaching while experimenting with Zoom in terms of sexual harassment and character assassination. In one recent case, a faculty member reported he was facilitated by one of the coordinators in running an online teaching session. After a while, one of the students ran a porn video in the middle which could not be stopped by him since neither he was a participant, host nor also, he had any control over the activity. A pure academic activity resulted in mere humiliation and ridicule by the students. The coordinator when inquired refused to share the identity of that student. Such incidents can pose long term implications on the psychosocial health of the faculty. Apart from this, many have complained to generalized anxiety and Obsessive Compulsive Disorders OCDs due to the recent transition to online learning. These cases are not much, but they are often used as scapegoats by some faculty members who are not ready to take the challenge of online teaching. Not only this, but also prolonged working in isolation that lacks face to face interaction which is a leading psycho-social risk for the university faculty is frequently reported (Dolan, 2011), (Yick, Patrick, \& Costin, 2005) \& (Fouche, 2006).

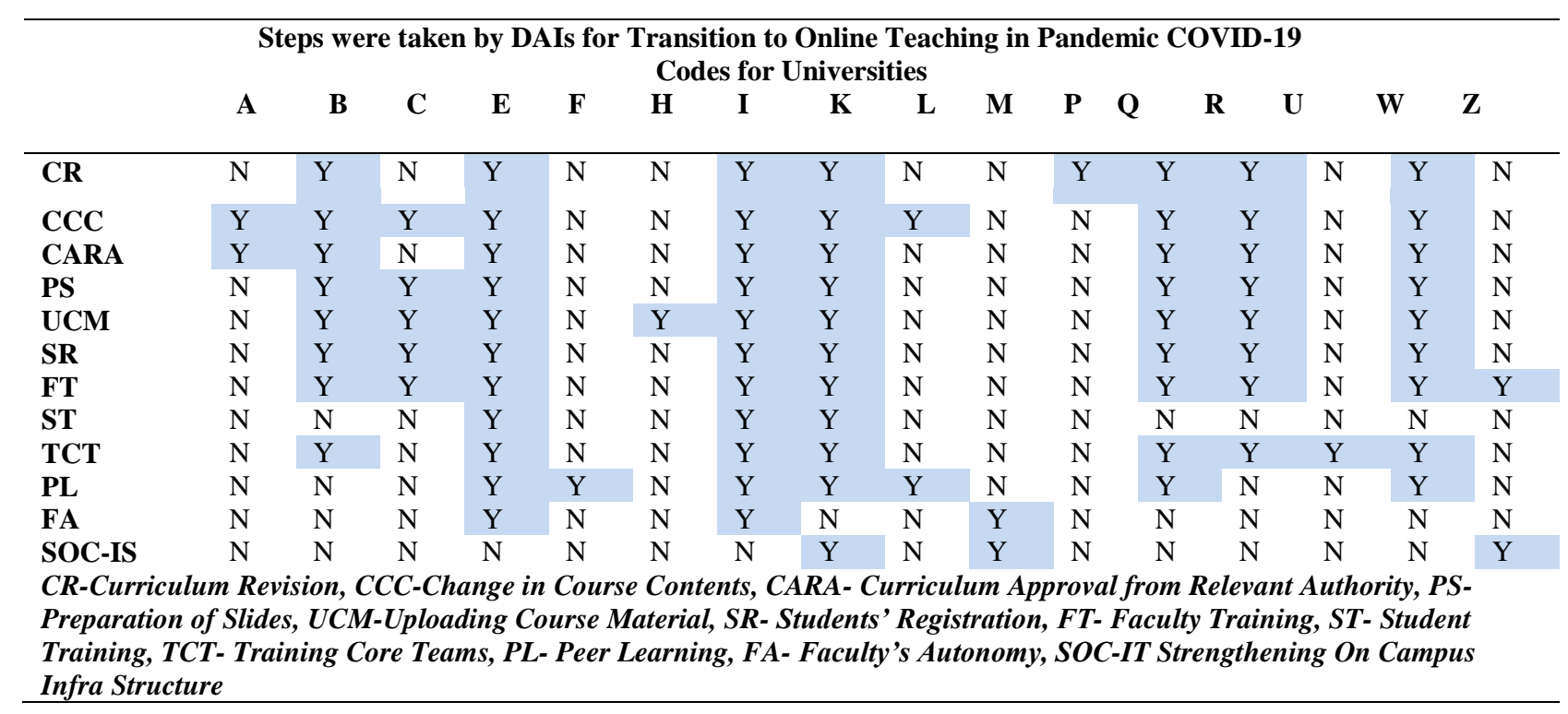




\section{Table No. 7: Steps taken by DAIs for Online Teaching Conclusion}

Online teaching in Pakistan other than the virtual and distance education model is altogether a new concept and has led to multiple experiments during the transition phase. It has appeared as an entire shift in the traditional edu-cultural paradigm in Pakistan to evolve. It is still the transition phase whereby the faculty, students, and their parents are trying to understand its logic and dynamics. The halt and transition in the academic process have served as a wakeup call to the higher education sector of Pakistan and exposed a lack of 'emergency preparedness'. However, to cope up with this emergency, several measures have been taken by the higher educational institutes. The steps taken by different universities in transition to online teaching are presented in table 7. Not all the universities have uniformly followed all the steps yet most are striving to keep pace with the guidelines devised by the higher education institutes. Quality of instruction is taken into account while designing models for online teaching which is generally absent in cases where it has been shifted in an emergency. An investment in the ecosystem of learner's support us required for effective online learning (Hodges, Moore, Lockee, Trust, \& Bond, 2020). Not just the Higher Education Commission of Pakistan, but also the Ministry of Information Technology and PEMRA needs to be taken on board for effective policy, planning and execution of online teaching in Pakistan. The Higher Education Commission of Pakistan has devised several policies to direct the universities to switch to the Learning Management System and developed certain yardsticks to ensure quality control in online teaching. However, the existing ground realities and experiences are pretty different. There are lots of gaps between policy and on-ground situation of the universities in terms of online readiness to cope with the pandemic. This paper is an attempt to highlight how the gaps in policy and current practice are resultantly stressing out of the faculty. Also, there is a need to lay off the fears of the faculty that is not techsavvy, to build their confidence and let go of their hesitation in the adaptation of the technology. Motivation from the university administration will serve as a driving force to let go of the techno stresses and develop online readiness.

\section{Recommendations}

$>\quad$ The current climate of pre- and during COVID-19 suggests that there is a need to identify risks and mitigation strategies for the emotional and mental wellbeing of the faculty members for sustainable teaching interventions.

$>\quad$ The faculty needs to be counselled -as opposed to mere administrative directives- this will not only serve as a motivator for faculty but will also bring them onboard. This will go a long way in preparing them for 'online readiness' to correspond in any pandemic situation. Also, learning and observing the work ethics and working hours by faculty and administration will help both to stay sound mentally and psychologically and will never lead to techno-stress.

The universities should consider opening regular FM channels which will need a one-time investment but their studios; both audio and visual can be later used for recording online lectures specializing in facilitating the visiting faculty and the faculty which is not tech-savvy indeed. Also, the quality of the lectures will be improved.

$>\quad$ Considering that once all the courses are taught and mentored through online mode once for 2 years (in case of a traditional masters program) and 1 year (for an MS/MPhil program), the course material, the entire course work will be ready with the department and the university for that very program which can be used in any such emergency circumstances such as natural disasters, any incident of political unrest in the country or health issue of the relevant faculty. These programs can be used in distance learning as well and can eventually serve in revenue generation of the universities as well.

$>\quad$ In classrooms that are well equipped audio-visually, recordings of the lectures can be done for future use. The universities will organically learn the significance of recording lectures which will eventually serve as soft audio-visual course files for future use. The model of virtual universities can be adopted and this pandemic leading to online teaching leaves us with some food for thought for the future. The resources will eventually be reduced by up to $50 \%$.

Universities following the model of a the-school initiative of the government can evolve a parallel model for themselves or can connect to them at another time for general courses. Also, back in 1992, Pakistan Television presented with ETV- a satellite channel that covered 
transmission in over 30 countries and was later closed due to financial liability- can be reactivated for online universities teaching for its outreach to distant local and international

References coverage.

Ahmed, H., Allaf, M., \& Elghazaly, H. (2020, March 23). COVID-19 and medical education. The Lancet Infectious Diseases.

Allen, I. E., Seaman, J., Lederman, D., \& Jaschik, S. (2012). Conflicted: Faculty and online education. Washington Inside Higher Education, Babson Survey Research Group, and Quahog Research Group.

Bao, W. (2020). COVID-19 and online teaching in higher education: A case study of Peking University. Human Behavior and Emerging Technologies, 2 (2), 113-115.

Bartoszko, A. (2020). The accelerating curve of anxiousness: How a governmental quarantine-app feeds society with bugs. Journal of Extreme Anthropology, 4 (1), 7-17.

Chartered Institute of Personnel Development. (2020, March). Health and Well Being at Work. Retrieved May 25, 2020, from www.cipd.co.uk: https://www.cipd.co.uk/Images/publicsector-summary_tcm18-73787.pdf

Dolan, V. (2011). The isolation of online adjunct faculty and its impact on their performance. International Review of Research in Open and Distributed Learning, 12 (2), 63-77.

Eurofound \& ILO. (2017, February 17). Working anytime, anywhere: The effects on the world of work. Retrieved May 26, 2020, from www.eurofound.europa.eu: https://www.eurofound. europa.eu/publications/report/2017/working-anytime-anywhere-the-effects-on-the-world-ofwork

European Agency for Safety and Health at Work. (2019, November 20). Third European survey of companies on new and emerging risks (SENER 3). Retrieved May 25, 2020, from www.osha.europa.eu:https://osha.europa.eu/es/publications/third-european-survey-enterprises -new-and-emerging-risks-designer-3/view

Fouche, I. (2006). A Multi-Island Situation Without the Ocean: Tutors' perceptions about working in isolation from colleagues. The International Review of Research in Open and Distributed Learning, 7 (2), 1-21.

García-González, M. A., Torrano, F., \& García-González, G. (2020). Analysis of stress factors for female professors at online universities. International Journal of Environmental Rsearch and Public Health, 17 (8), 2958.

Health and Safety Executive. (2019, October). Health and Safety at Work: Summary Statistics for Great Britain 2019. Retrieved May 26, 2020, from www.hse.gov.uk: https://www.hse.gov.uk/ statistics/overall/hssh1819.pdf

HEC. (2020, April 14). Why Online Education? Retrieved May 23, 2020, from www.hec.gov.pk: https://www.hec.gov.pk/english/HECAnnouncements/Pages/Why-Online-Education.aspx

Hodges, C., Moore, S., Lockee, B., Trust, T., \& Bond, A. (2020). The difference between emergency remote teaching and online learning. Educause Review, 27.

Khan, A. A., Niazi, S., \& Saif, S. K. (2020, March 26). Universities were unprepared for switch to remote learning. Retrieved May 24, 2020, from www.universityworldnews.com: https://www.universityworldnews.com/post.php?story=20200326141547229

Khattak, K. (2020, March 27). Campuses to remain closed till May 31. Retrieved May 25, 2020, from https://www.thenews.com.pk/print/635162-campuses-to-remain-closed-till-may-31: https://www.thenews.com.pk/print/635162-campuses-to-remain-closed-till-may-31

Latif, A., \& Sajid, I. (2020, March 13). Pakistan closes schools, universities over coronavirus. Retrieved May 2020, 24, from www.aa.com.tr: https://www.aa.com.tr/en/asia-pacific/pakistan -closes-schools-universities-over-coronavirus/1765276

Lazarus, B. D. (2003). Teaching courses online: How much time does it take? Journal of Asynchronous Learning Networks, 7 (3), 47-54.

Lin, C., Singer, R., \& Ha, L. (2010). Why university members use and resist technology? A structure enactment perspective. Journal of Computing in Higher Education, 22 (1), 38-59. 
Malik, N. A., Björkqvist, K., \& Österman, N. (2017). Factors associated with occupational stress among university teachers in Pakistan and Finland., 6(2), 1-14. Journal of Educational, Health, and Community Psychology, 6 (2), 1-14.

Messenger, J. C., \& Gschwind, L. (2016). Three generations of Telework: New ICT s and the (R) evolution from the Home Office to Virtual Office. New Technology, Work and Employment, 31 (3), 195-208.

Mitchell, L. D., Parlamis, J. D., \& Claiborne, S. (2015). Overcoming Faculty Avoidance of Online Education: From Resistance to Support to Active Participation. Journal of Management Education, 39 (3), 350-371.

O’Laughlin, E. M., \& Bischoff, L. G. (2005). Balancing parenthood and academia. Work/family stress as influenced by gender and tenure status. Journal of Family Issues, 26, 79-106.

Olson-Buchanan, J. B., \& Boswell, W. R. (2006). Blurring boundaries: Correlates of integration and segmentation between work and nonwork. , 68(3),. Journal of Vocational Behavior, 68 (3), $432-445$.

Pace, F., D’Urso, G., Zappulla, C., \& Pace, C. (2019). The relation between workload and personal well-being among university professors. Current Psychology, 1-8.

Pakistan Today. (2020, May 12). Closure of universities likely to be extended: HEC. Retrieved May 25, 2020, from https://www.pakistantoday.com.pk/2020/05/12/closure-universities-likelyextended-hec/:https://www.pakistantoday.com.pk/2020/05/12/closure-universities-likely-extended-hec/

Palloff, R., \& Pratt, K. (2007). Building online learning communities. San Francisco: CA: Josey-Bass.

Parlamis, J., \& Mitchell, L. D. (2014). Teaching negotiations in the new millennium: Evidence-based recommendations for online course delivery. Negotiation Journal, 30, 93-113.

Pasha, Z. (2020, May 13). COVID-19's impact on education. Retrieved May 22, 2020, from www.nation.com.pk: https://nation.com.pk/13-May-2020/covid-19-s-impact-on-education

Pickup, S. (2020, April 22). Occupational wellbeing amidst a global health pandemic. The Psychologist

Rose, S. (2020, March 31). Medical Student Education in the Time of Covid-19. JAMA.

Salanova, M., Llorens, S., \& Cifre, E. (2013). The dark side of technologies: Techno-stress among users of information and communication technologies. International Journal of Psychology, 48 (3), $422-436$.

Self, D. R., \& Schraeder, M. (2009). Enhancing the success of organizational change: Matching readiness strategies with sources of resistance. Leadership \& Organisational Management Journal, 30, 167-182.

Tarafdar, M., Qiang, T., Ragu-Nathan, B. S., \& Ragu-Nathan, T. S. (2007). The Impact of Technostress on Role Stress and Productivity. Journal of Management Information Systems, 24 (1), 301-328.

UNESCO. (2020, March 30). COVID-19 Webinar: A new world for teachers, education's frontline workers - COVID-19 education webinar \#2. Retrieved May 24, 2020, from www.unesco.org: https://en.unesco.org/news/covid-19-webinar-new-world-teachers-educations-frontline-workers-covid-19-education-webinar-2

WHO. (2020, March 11). WHO Director-General's opening remarks at the media briefing on COVID-19 - 11 March 2020. Retrieved May 1, 2020, from https://www.who.int/dg/ speeches/detail/who-director-general-s-opening-remarks-at-the-media-briefing-on-covid-19--11-march-2020:https://www.who.int/dg/speeches/detail/who-director-general-s-openingremarks-at-the-media-briefing-on-covid-19---11-march-2020

Wladis, C., \& Samuels, J. (2016). Do online readiness surveys do what they claim? Validity, reliability, and subsequent student enrollment decision. Computers \& Education, 98, 39-56.

Xie, J., Ma, H., Zhou, Z. E., \& Tang, H. (2018). Work-related use of information and communication technologies after hours (W_ICTs) and emotional exhaustion: A mediated moderation model. Computers in Human Behavior, 94-104.

Yick, A. G., Patrick, P., \& Costin, A. (2005). Navigating distance and traditional higher education: Online faculty experiences. The International Review of Research in Open and Distributed Learning, 6 (2), 1-18. 
Yukl, G. A. (2006). Leading change in organizations. Leadership in organizations (6th ed., pp. 284314). New Jersey.

Zimmerman, J. (2020, March 2020). Coronavirus and the Great Online-Learning Experiment. Retrieved May 25, 2020, from www.chronicle.com: https://www.chronicle.com/article/ Coronavirusthe-Great/248216 